\title{
Effect of Five Organic Soil Amendments on Meloidogyne Incognita Infecting Tomato Plants under Greenhouse Conditions
}

\author{
A. G. El-Sherif1 ${ }^{1}$, S. B. Gad'1 A. M. Khalil'2, Rabab H. E. \\ Mohamedy ${ }^{3}$
}

1Nematology Res. Unit, Agric. Zoology Dept., Fac. of Agric., Mansoura Univ., Egypt.

2Nematology Division, Plant pathology Inst. Res. A.R.C., Giza, Egypt.

3Plant protection Dept. Fac. Of Agric., Aswan Univ., Egypt

\begin{abstract}
A pot experiment was conducted in order to study the impact of time application of four animal manures i.e. chicken, horse, farm-yard and pigeon manures and town refuse added separately either pre or post planting treatments comparing to oxamyl on tomato plant $\mathrm{cv}$. Castle Rock infected with $M$. incognita under greenhouse conditions $\left(25 \pm 3^{\circ} \mathrm{C}\right)$. Results revealed that all tested materials clearly enhanced plant growth characters to great degree and reduce gall and eggmass numbers. Plant receiving pigeon manure as pre-planting or post planting applications at the level of $5 \mathrm{~g} / \mathrm{plant}$ obviously surpassed other tested animal manures and town refuse in the increment values of plant length (85.7 and 71.4\%), total plant fresh weight (66.4 and 37.9\%) number of flowers (100 and $100 \%$ ), fruits (300 and $400 \%)$, and branches/plant(100 and 300\%) and shoot dry weight (42.9 and 38.1\%), as well as achieved the highest reduction percentage for number of root galls $(89.1$ and $81.5 \%)$, eggmasses (90 and $84.2 \%$ ), for pre or post planting applications, respectively followed by farm-yard manure where as chicken treatment as a pre-planting soil amendments exhibited the lesser values in this respect. All treatments obviously gave sizeable percentage increase values of nitrogen $(\mathrm{N})$, phosphorus $(\mathrm{P})$, potassium $(\mathrm{K})$, organic matter $(\mathrm{O} . \mathrm{M})$, and organic carbon(O.C) in leaves of tomato plant. The pigeon or chicken manures showed also very narrow $\mathrm{C} / \mathrm{N}$ ratio (12.6:1) or (14.3:1), respectively, in this work. Among the tested materials, pigeon manure ranked first in percentage increase values of chemical components of leaves as pre-planting application, whereas chicken manure showed this position as post-planting treatment.
\end{abstract}

Keywords: Chicken, Horse, Farm-Yard, Pigeon, Manures, Town Refuse, Meloidogyne Incognita, Control, Tomato

\section{INTRODUCTION}

The root-knot nematode, Meloidogyne incognita is the major nematode species that parasitize economic plants in Egypt (Ibrahim and El-Saedy, 1976). Tomatoes are one of the most common vegetable fruits in Egypt. Phytonemtodes especially the root knot nematode is known to be the most common tomato pests. Moreover, it is well known that nematicides are costly and potentially harmful to the environment. Meanwhile, the improvement in plant growth and yield criteria after the addition of organic matter due to the disinfection of such animal manure as fertilizers were recorded by several investigators (Siddiqui and Alam 1988, El-Sherif et al., 2001, 2004, 2006). Organic soil amendments have been widely used for management of plant-parasitic nematodes. Relatively rapid declines in nematode population levels may occur when decomposing organic materials release toxic compounds, while longer-term effects might include increases in nematode antagonists. Improved crop nutrition and plant growth following organic amendments use may lead to tolerance of plant-parasitic nematodes (McSorley, 2011). Decomposing organic matter is food for many soil microbes i.e. fungi, actinomycetes, and bacteria. Some of those creatures are natural enemies of plant nematodes; increasing their numbers enhances "natural" nematode control (Crow and Dunn, 2013). Therefore, the present investigation was carried out to study the effect of five organic soil amendments i.e. chicken, horse, farm-yard and pigeon manures; and town refuse on

This article is published under the terms of the Creative Commons Attribution License 4.0 Author(s) retain the copyright of this article. Publication rights with Alkhaer Publications. Published at: http://www.ijsciences.com/pub/issue/2015-06/

Article Number: V4201506748; Online ISSN: 2305-3925; Print ISSN: 2410-4477 
M. incognita infecting tomato plants under greenhouse conditions.

\section{MATERIALS AND METHODS}

1. Nematode stock culture, propagations and preparing nematode inoculum:

To collect and determine the inocula of Meloidogyne incognita eggs; $M$. incognita was previously identified according to Taylor $\boldsymbol{e t}$ al. (1955). Infected root systems with heavy eggmasses of $M$. incognita of various growing coleus, Coleus blumei plants, grown in $25 \mathrm{~cm}$-diam plastic pots filled with sterilized clayey soil, at the Nematology Research unit (NERU). Unit, Agricultural Zoology Department, Faculty of Agriculture, Mansoura University, Egypt, were well washed and cleaned by running tap water, then placed in a plastic container with enough solution of $1.0 \% \mathrm{NaOCl}$ for 60 seconds, shaked vigorously (manually) then quickly passed through nested sieves and thoroughly washed the collected eggs with tap water to remove the bleach(Hussey and Barker, 1973). Eventually, the number of eggs per unit volume of water was counted and then plants were inoculated directly with eggs according to the design of each experiment of this work which was carried at the greenhouse of Nematological Research Unit (NERU).

\section{2-Pesticide}

Oxamyl (Vydate 24\% L.) Methyle-N-N-dimethyl(N-(methyl) carbomycocyl)-1-Thioxamidate.

\section{3-Preparation of Organic soil mterials:}

Four animal manures i.e. chicken, horse, farm-yard and pigeon-dung, ; and town refuse were separately collected, sun-dried on a sheet of paper and kept within a plastic bag until use, where the dose of each was $5 \mathrm{~g} / \mathrm{plant} /$ pot that added according to the design of each experiment.

4-Influence of five Organic Materials on Adjusting Meloidogyne incognita Infecting Tomato plants comparing to Oxamyl under Greenhouse Conditions $\left(25 \pm 3^{\circ} \mathrm{c}\right)$.

In order to examine the impact of four organic manures ,i.e. chicken ,farm-yard ,horse ,and pigeondung; and town refuse in comparison with oxamyl at the recommended dose on controlling Meloidogyne incognita infecting tomato plant cv. Castle Rock under greenhouse conditions $\left(25 \pm 3^{\circ} \mathrm{c}\right)$,fifty two plastic pots $(15 \mathrm{~cm}$-diam.)containing $1600 \mathrm{~g}$ steam sterilized clay sand $(1: 1, \mathrm{v}: \mathrm{v})$ with one tomato seedling 30 days old each were used in this study. Two trials with twenty pots each,one as a pre-planting and the other as a post-planting applications were included .Pots of the first trial received the dose of tested organic materials as soil amendments at the level of $5 \mathrm{~g} /$ pot mixed with soil, irrigated with tap water and left for decomposition one week before tomato seedling transplanting. One week later, the dose of tested materials separately mixed with soil at the level of $5 \mathrm{~g} /$ pot for four replicates each of the postplanting trial: One week after that ,1000Meloidogyne incognita eggs separately added to forty eight pots (seedlings), where four seedlings with nematode received oxamyl at the rate of $0.3 \mathrm{ml}$ per pot (seedling),four seedlings (pots) with nematode only and another four seedlings (pots) without nematode and any treatment. Each treatment was replicated four times. Treatments were as followed:

\section{A-Pre-planting trial:}

1-N+chicken manure $5 \mathrm{~g} / \mathrm{pot})$, $2-\mathrm{N}+$ farm yard manure $(5 \mathrm{~g} / \mathrm{pot})$, $3-\mathrm{N}+$ horse manure $(5 \mathrm{~g} / \mathrm{pot})$, $4-\mathrm{N}+$ pigeon dung $(5 \mathrm{~g} / \mathrm{pot})$, 5 - $\mathrm{N}$ +town refuse $(5 \mathrm{~g} / \mathrm{pot})$,

\section{B-Post-planting trial:}

6-N+chicken manure (5g/pot), yard manure $(5 \mathrm{~g} / \mathrm{pot})$,

8 -N+horse manure (5g/pot),

$7-\mathrm{N}+$ farm-

$\mathrm{N}+$ pigeon dung $(5 \mathrm{~g} / \mathrm{pot})$

$10-\mathrm{N}+$ town refuse $(5 \mathrm{~g} / \mathrm{pot})$,

$\mathrm{N}+$ oxamyl $(0.3 \mathrm{ml} / \mathrm{pot})$

12-N alone and 13.plant free of Nematode and any treatment.

Plastic pots were then arranged in randomized and complete block design in the greenhouse and treated horticulturally, protected against mites and insects by conventional pesticide, and irrigated with tap water as needed. Plants were harvested after 45 days from nematode inoculation and plant growth parameters i.e. shoot and root length and fresh weights as well as dry weights, number of branches, flowers and fruits/plant were determined and recorded .Infected roots of each plant per treatment were washed with tap water, fixed in $4 \%$ formalin for $24 \mathrm{~h}$ and then examined for the number of galls and eggmasses per root system and recorded. The root gall index (RGI) and egg mass index (EI) were estimated according to the scale given by Taylor and Sasser (1978) as follows: $0=$ no galls or egg-masses, $1=1-2$ galls or egg-masses, $2=3-10$ galls or egg-masses, $3=11-30$ galls or egg-masses, $4=31-100$ galls or egg-masses and $5=$ more than 100 galls or egg-masses

\section{Statistical analysis:}

Statistically, the obtained data were subjected to analysis of variance (ANOVA) (Gomez and Gomez, 1984), followed by Duncan's multiple range Tested (DMRT) to compare means (Duncan, 1955).

Chemical analysis:

Nitrogen $(\mathrm{N})$, phosphorus $(\mathrm{P})$, potassium(K), organic matter(OM) and carbon(O.C) as well as chlorophyll 
content were determined according to Kjeldahl methods (A.O.A.C., 1980).

Determination of total phenols:

In this experiment, total phenols were determined after harvesting in fresh leaves bases using the FolinCiocalteau reagent (Kaur and Kapoor 2002). Total catechol equivalents by the following equation:

$$
\mathrm{T}=\mathrm{c} \times \mathrm{V} / \mathrm{m} \times 100
$$

Where:

$\mathrm{T}$ - Total content of phenolic compounds, in mg of catechol/100 g of fresh weight material.

C- The concentration of catechol established from the calibration curve, in $\mathrm{mg} / \mathrm{ml}$.

$\mathrm{V}$ - The volume of extract in $\mathrm{ml}$.

$\mathrm{m}$-The weight of pure plant ethanolic extracting.

\section{RESULTS AND DISCUSSION}

Data in Table (1) illustrate the impact of four animal manures and town refuse added as Pre-planting treatments to tomato plant cv.. Castle Rock infected with $M$. incognita in comparison with oxamyl at-the recommended dose under greenhouse conditions $\left(25 \pm 3^{\circ} \mathrm{C}\right)$. Results revealed that all tested materials obviously improved plant growth characters to great extent. Plant receiving pigeon manure as pre-planting application at the level of $5 \mathrm{~g} / \mathrm{plant}$ obviously surpassed other tested animal manures and town refuse in the increment values of plant length $(85.7 \%)$, total plant fresh weight $(66.4 \%)$ number of flowers (100\%), fruits(300\%), and branches/plant $(100 \%)$ and shoot dry weight $(42.9 \%)$, followed by farm-yard manure with percentage increase values of $71.4,48.3,20,75,100$ and $38.1 \%$ for the same plant growth criteria, compared to nematode alone (Table 1). However, plant receiving horse manure or town refuse applications achieved the intermediate considerable percentage increase values of the same plant growth characters comparing to nematode alone, respectively, whereas chicken treatment as a pre-planting soil amendments exhibited the lesser percentage increase values of plant length(48.6\%), total plant fresh weight(20.7\%), number of flowers(20\%), fruits (100\%), branches/plant $(62.5 \%)$ and shoot dry weight $(14.3 \%)$ as compared to nematode alone, respectively .Oxamyl as a systemic nematicide ranked first in percentage increase values of plant length $(86.8 \%)$, total plant fresh weight $(85.5 \%)$, number of flowers $(100 \%)$, fruits $(300 \%)$, branches/plant $(217.5 \%)$ and shoot dry weight $(85.7 \%)$, comparing to nematode alone. It is interesting to note that plant free of nematode and any treatments showed considerable percentage increase values of 7.1, 8.6, 0.0, 25, 60, and $4.8 \%$ for the same plant growth parameters as compared to nematode alone, respectively (Table 1). 
Effect of Five Organic Soil Amendments on Meloidogyne Incognita Infecting Tomato Plants under Greenhouse Conditions

Table(1): Plant growth response of tomato plant cv. Castel Rock infected with Meloidogyne incognita treated by five organic materials added as pre-planting application comparing to oxamyl under greenhouse conditions $\left(25 \pm 3^{\circ} \mathrm{c}\right)$.

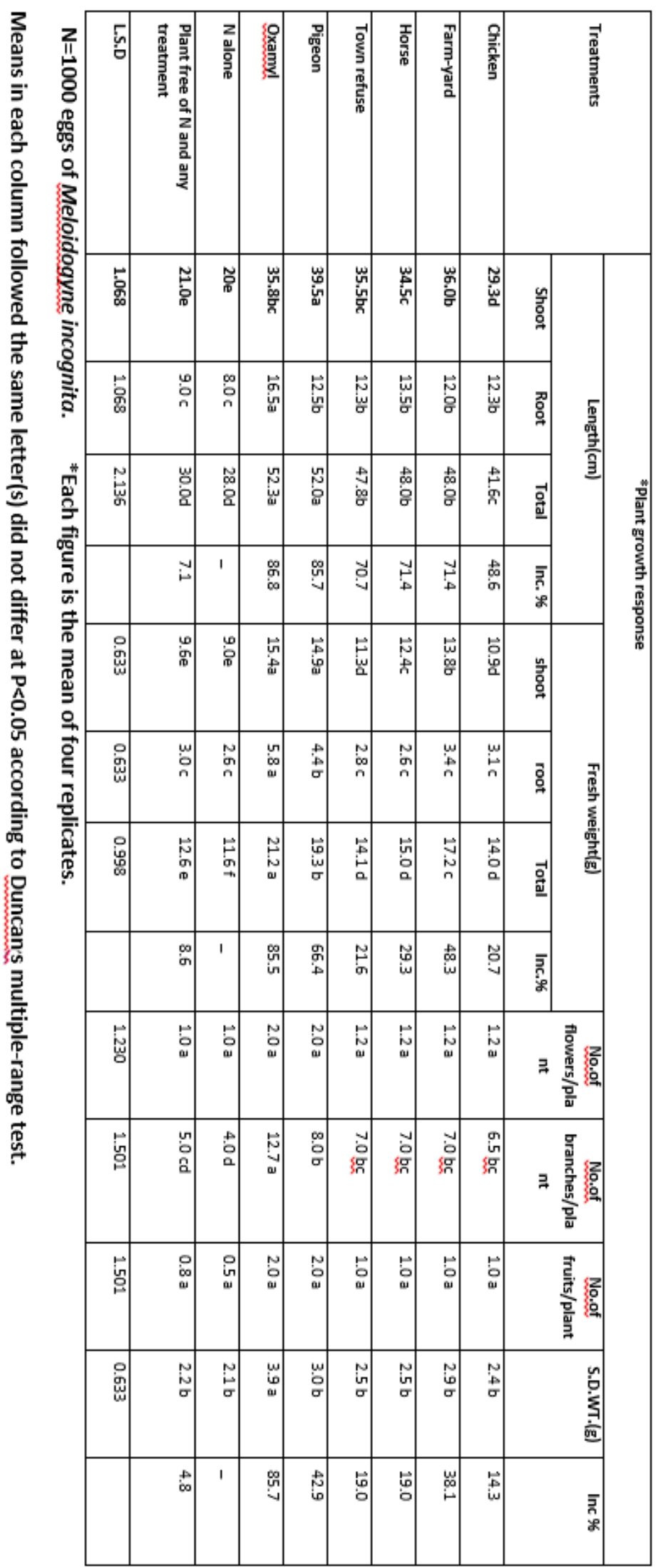


Data presented in Table(2) documented the influence of four animal manures i.e. chicken, farm-yard, horse and pigeon, and town refuse added as post- planting applications to tomato plant CV. Castel Rock infected with Meloidogyne incognita in comparison with oxamyl at the recommended dose under greenhouse conditions $\left(25 \pm 3^{\circ} \mathrm{c}\right)$. Results generally indicated that all tested organic soil amendments at the level of $5 \mathrm{~g} / \mathrm{plant}$ ameliorated plant growth parameters to various degrees. Among the four treatments tested, pigeon manure overwhelmed other materials in the increment percentage values that were amounted to $71.4,37.9,100,400,300$, and $38.1 \%$ for plant length, total plant fresh weight, number of flowers, branches and fruit per plant and shoot dry weight followed by that of farm-yard manure with values of $42.9,24.1,20,75,100$ and $19 \%$ for the same plant growth parameters comparing to nematode alone, respectively. In the meantime, plant receiving horse manure as post-planting application showed the intermediate position in percentage increase values of plant length $(35.7 \%)$, total plant fresh weight $(20,7 \%)$, number of flowers /plant(20\%), number of branches/plant(50\%), number of fruits/plant(100\%), and shoot dry weight(9.5\%), respectively, whereas, chicken manure and town refuse as soil amendments treatments at the level of $5 \mathrm{~g} /$ plant each (post-planting) achieved the lesser values of the same plant growth characters and were on par in their values comparing to nematode alone, respectively. Oxamyl as a systemic nematicide ranked first in percentage increase values of plant length $(86.8 \%)$, total plant fresh weight(82.8\%), number of flowers(100\%), branches $(217.5 \%)$ and fruits $(300 \%) /$ plant; and shoot dry weight $(85.7 \%)$, respectively, comparison to nematode alone(Table 2 ).

It is worthy to note that plant receiving none of any treatments and no nematode gave reasonable percentage increase values of plant length(7.1\%), total plant fresh weight $(8.6 \%)$, number of flowers/plant(zero \%), number of branches(25\%), number of fruits/plant $(60 \%)$, and shoot dry weight $(4.8 \%)$ as compared to nematode alone, respectively.(Table 
Effect of Five Organic Soil Amendments on Meloidogyne Incognita Infecting Tomato Plants under Greenhouse Conditions

Table (2). Plant growth response of tomato plant cv. Castel Rock infected with Meloidogyne incognita treated by four organic materials added as post-planting application in comparison with oxamyl under greenhouse conditions $\left(25 \pm 3^{\circ} \mathrm{C}\right)$.

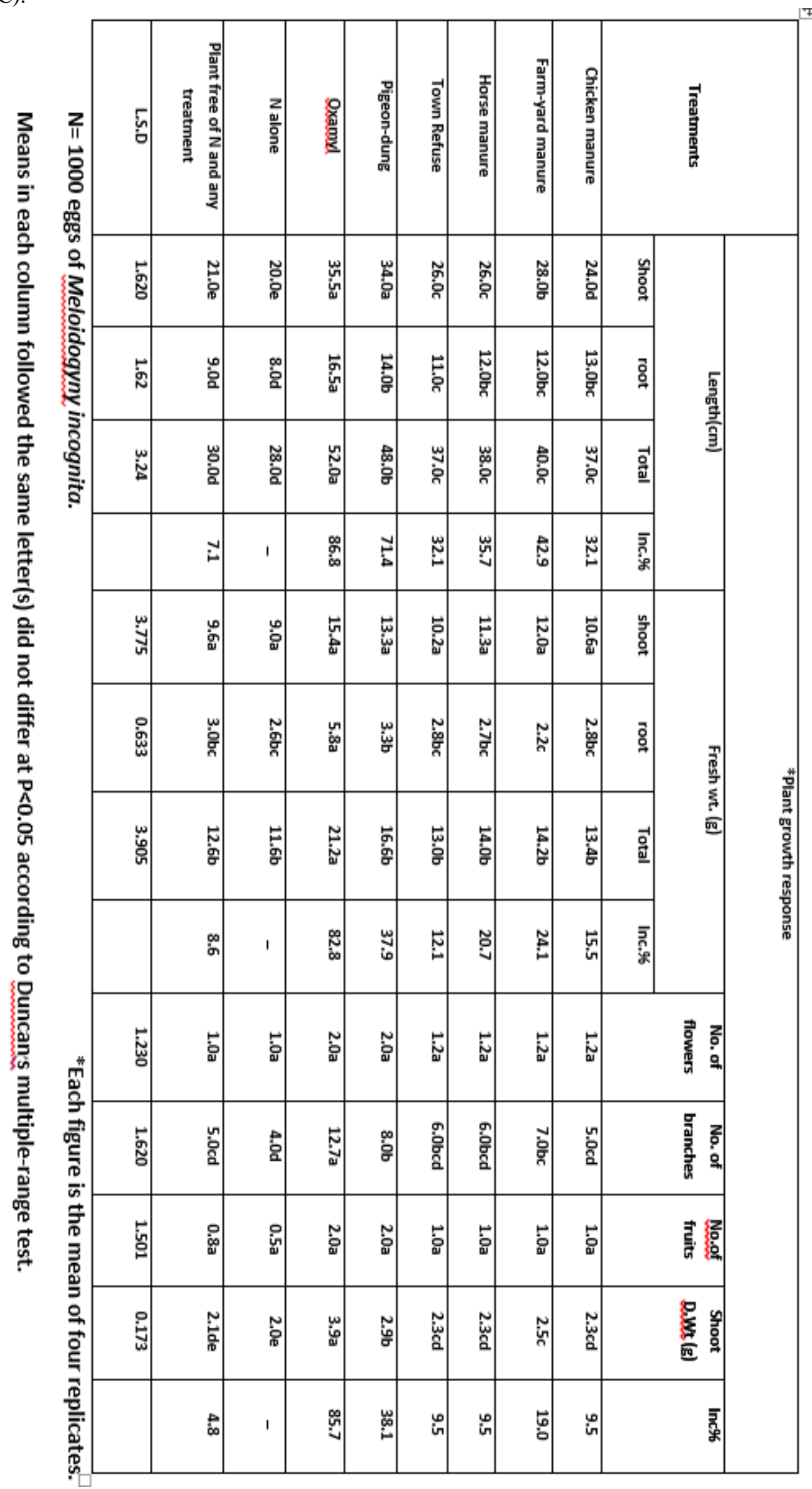


Effect of Five Organic Soil Amendments on Meloidogyne Incognita Infecting Tomato Plants under Greenhouse Conditions

Data in Table (3) presented the reduction percentage of $M$. incognita number of galls and eggmasses on tomato root system as affected by the addition of four animal manures of chicken, farm-yard, horse and pigeon, and town refuse as pre-planting applications at the level of $5 \mathrm{~g} / \mathrm{plastic} / \mathrm{pot}$ in comparison with oxamyl at the recommended dose under greenhouse conditions $\left(25 \pm 3^{\circ} \mathrm{c}\right)$.Obviously root galls and eggmasses number of Meloidogyne incognita on tomato plant root system were greatly affected by all treatments applied as compared to the nematode alone (Table 2).Among the tested soil amendment materials, pigeon manure (5g/plant) as a pre-planting application significantly achieved the highest reduction percentage for number of root galls $(89.1 \%)$, eggmasses $(90 \%)$, followed by that of farm-yard manure, horse manure, town refuse and then chicken manure, with values of $88.2 \& 89.0 \%$; $87.3 \& 88.0 ; 85.5 \& 88 \%$, ; and $85.5 \& 86.0 \%$, respectively comparing to nematode alone (Table 3 ). Oxamyl as a systemic nematicide at the recommended dose significantly ranked first in reduction percentage values of root galls and eggmasses number which were amounted to 90.9 and $99.5 \%$, respectively as compared to nematode alone (Table 3). Likewise, significant results were also observed between eggmasses indices of all tested materials as pre-planting applications and nematode alone, since they ranged from 3 for chicken, farmyard, horse manures and town refuse or 2 for pigeon manure vs 4 for nematode alone. Similar results were recorded in the case of root galls indices that were appointed to 3 for the tested materials vs. 5 for nematode alone, whereas Oxamyl showed root gall and eggmasses indices values of 2 and zero vs 5 or 4 for nematode alone, respectively (Table 3).

Data in Table (4) revealed the reduction percentages of Meloidogyne incognita numbers of root galls and eggmasses on tomato root system as influenced by the addition of soil amendments such as chicken, farm-yard, horse, and pigeon manures; and town refuse at the level of $5 \mathrm{~g}$ /plant as post-planting applications in comparison with oxamyl at the recommended dose in the greenhouse conditions $\left(25 \pm 3^{\circ} \mathrm{C}\right)$. Results obviously indicated that number of root galls and eggmasses of Meloidogyne incognita on tomato plant root system were affected by the organic materials added as post-planting treatments in comparison to nematode alone (Table 4). Among the tested materials, pigeon manure remarkably surpassed other materials in diminishing numbers of root galls and eggmasses with values of 81.5 and $84.2 \%$, respectively, followed by that of farm-yard manure with values of 80.9 and $82.7 \%$ for the same nematode criteria, respectively, whereas town refuse treatment showed the lesser values of the same nematode criteria, comparing to nematode alone (Table 4). Moreover, plant receiving either chicken or horse manures as post-planting applications recorded almost equal reduction percentage values of root galls(78.8\% \& 78.8\%) and eggmasses $(82.0 \%$ \& $79.0 \%)$, respectively, comparing to nematode alone. Oxamyl as a systemic nematicide ranked first in reduction percentage values of root galls $(90.0 \%)$ and eggmasses $(99.5 \%)$ number as compared to nematode alone. 
Effect of Five Organic Soil Amendments on Meloidogyne Incognita Infecting Tomato Plants under Greenhouse Conditions

\begin{tabular}{|c|c|c|c|c|c|c|}
\hline \multirow{2}{*}{ Treatments } & \multicolumn{6}{|c|}{ * Nematode Parameters } \\
\hline & No. of galls & $\operatorname{Red} \%$ & RGI\% & No. of eggmasses & $\operatorname{Red} \%$ & EI \\
\hline Chicken & $16 \mathrm{~b}$ & 85.5 & 3 & $14 \mathrm{~b}$ & 86.0 & 3 \\
\hline Farm-yard & $13 \mathrm{~cd}$ & 88.2 & 3 & $11 \mathrm{c}$ & 89.0 & 3 \\
\hline Horse & 14 bcd & 87.3 & 3 & $12 \mathrm{c}$ & 88.0 & 3 \\
\hline Town Refuse & $15 \mathrm{bc}$ & 85.5 & 3 & $12 \mathrm{c}$ & 88.0 & 3 \\
\hline Pigeon & $12 \mathrm{~d}$ & 89.1 & 3 & $10 \mathrm{c}$ & 90.0 & 2 \\
\hline Oxamyl & $10 \mathrm{e}$ & 90.9 & 2 & $0.5 \mathrm{~d}$ & 99.5 & $\mathbf{0}$ \\
\hline N alone & $110 \mathrm{a}$ & & 5 & $100 \mathrm{a}$ & & 4 \\
\hline L.S.D & 1.751 & & & 1.622 & & \\
\hline
\end{tabular}

Table (3): Impact of five organic materials added as pre-planting in comparison applications with oxamyl on number of root galls and eggmasses of Meloidogyne incognita infecting tomato plant cv. Castel Rock under greenhouse conditions $\left(25 \pm 3^{\circ} \mathrm{c}\right)$.

$\mathrm{N}=1000$ eggs of Meloidogyne incognita. $\quad *$ Each figure is the mean of four replicates.

Means in each column followed the same letter(s) did not differ at $\mathrm{P}<0.05$ according to Duncan's multiple-range test.

Table(4): Impact of five organic materials added as post-planting applications in comparison with oxamyl on number of galls and eggmasses of Meloidogyne incognita infecting tomato plant cv. Castel Rock under greenhouse conditions $\left(25 \pm 3^{\circ} \mathrm{c}\right)$.

\begin{tabular}{|c|c|c|c|c|c|c|}
\hline \multirow{2}{*}{ Treatments } & \multicolumn{6}{|c|}{ * Nematode Parameters } \\
\hline & No. of galls & $\operatorname{Red\% }$ & RGI\% & No.of eggmasses & Reed\% & RGI\% \\
\hline Chicken manure & $23.3 \mathrm{~b}$ & 78.8 & 3 & $18.0 \mathrm{c}$ & 82.0 & 3 \\
\hline Farm-yard manure & $21.0 \mathrm{c}$ & 80.9 & 3 & $17.3 \mathrm{c}$ & 82.7 & 3 \\
\hline Horse manure & $23.3 \mathrm{~b}$ & 78.8 & 3 & $21.0 \mathrm{~b}$ & 79.0 & 3 \\
\hline Town Refuse & $23.5 \mathrm{~b}$ & 78.6 & 3 & $22.0 \mathrm{~b}$ & 78.0 & 3 \\
\hline Pigeon-dung & $20.3 \mathrm{c}$ & 81.5 & 3 & $15.8 \mathrm{~d}$ & 84.2 & 3 \\
\hline Oxamyl & $10.0 \mathrm{~d}$ & 90.9 & 2 & $0.5 \mathrm{e}$ & 99.5 & 0 \\
\hline $\mathbf{N}$ alone & 110.0 a & - & 5 & 100.0 a & - & 4 \\
\hline L.S.D & 1.154 & & & 1.328 & & \\
\hline
\end{tabular}

$\mathrm{N}=1000$ eggs of Meloidogyne incognita . * *Each figure is the mean of four replicates.

Means in each column followed the same letter(s) did not differ at $\mathrm{P}<0.05$ according to Duncan's multiple-range test.

Data in Tables (5\&6) illustrate the percentage increase values of nitrogen $(\mathrm{N})$, phosphorus $(\mathrm{P})$, potassium(K), organic matter(O.M), and organic carbon(O.C) in leaves of tomato plant cv. Castel Rock treated by four animal manures i.e. chicken, pigeon, horse, and farm-yard, and town refuse either as pre-planting (Table 5) or post-planting (Table 6) applications comparing to oxamyl at the recommended dose under the stress of Meloidogyne incognita infection in the greenhouse coditions. In general, all treatments obviously gave considerable percentage increase values of all tested chemical components of tomato leaves (Tables 5\&6). It is interesting to observe that pigeon manure as preplanting applications accomplished the highest percentage increase values of $\mathrm{N}(65.2 \%), \mathrm{P}(44.8 \%)$, K (43.1\%), O.M (9.8\%). O.C (30.0\%) with C/N ratio 13.5:1, as compared to nematode alone (Table 5) followed by town refuse and chicken manure treatments, whereas horse manure assigned the intermediate position in percentage increase values of all items tested. In the meantime, farm-yard manure showed the lowest percentage increase values that averaged $33.5,20.3,18.1,5.5$ and $5.5 \%$ for $\mathrm{N}, \mathrm{P}, \mathrm{K}$, $\mathrm{OM}$ and O.C with $\mathrm{C} / \mathrm{N}$ ratio of 11.89 : 1 , respectively comparing to nematode alone (Table 5). It is worthy to note that applying such manures or town refuse as pre-planting treatments for tomato plants gave better results in improving chemical components of leaves than as post-planting applications. Moreover, among the materials tested, pigeon-manure ranked first in percentage increase values of chemical components of leaves when applied as pre-planting, (Table 5) whereas, chicken manure showed this position when applied as post-planting treatment (Table 6). Oxamyl as a systemic nematicide surpassed all tested treatments in Tables $(5 \& 6)$ in increasing percentage values of $\mathrm{N}(67.4 \%), \mathrm{P}(46.0 \%), \mathrm{K}(40.9 \%)$, $\mathrm{OM}(11.1 \%), \mathrm{O} . \mathrm{C}(9.0 \%)$ with $\mathrm{C} / \mathrm{N}$ ratio of $11.42: 1$ as compared to nematode alone, respectively. 
Effect of Five Organic Soil Amendments on Meloidogyne Incognita Infecting Tomato Plants under Greenhouse Conditions

Table (5): Average percent of nitrogen, phosphorus, potassium, organic matter and carbon in leaves of tomato plant cv. Castel Rock under the stress of Meloidogyne incognita infection treated with four animal manures and town refuse as pre-planting applications comparing with oxamyl in greenhouse conditions .

\begin{tabular}{|c|c|c|c|c|c|c|c|c|c|c|}
\hline \multirow[b]{2}{*}{ Treatments } & \multicolumn{10}{|c|}{ *Chemicals Component in Leaves } \\
\hline & N\% & Inc.\% & P\% & Inc.\% & $\mathrm{K} \%$ & Inc.\% & O.M & Inc.\% & O.C & $\begin{array}{l}\mathrm{C} / \mathrm{N} \\
\text { ratio }\end{array}$ \\
\hline $\begin{array}{l}\text { Chicken } \\
\text { manure }+\mathbf{N}\end{array}$ & 3.56 & 61.1 & 0.445 & 41.3 & 4.55 & 37.0 & 72.05 & 10.13 & 41.89 & 11.77:1 \\
\hline $\begin{array}{l}\text { Town-Refuse } \\
+\mathrm{N}\end{array}$ & 3.61 & 63.3 & 0.453 & 43.8 & 4.60 & 38.6 & 72.41 & 10.68 & 42.10 & 11.66:1 \\
\hline Pigeon + N & 3.65 & 65.2 & 0.456 & 44.8 & 4.75 & 43.1 & 71.83 & 9.79 & 49.44 & 13.67:1 \\
\hline $\begin{array}{l}\text { Horse } \\
\text { manure + N }\end{array}$ & 2.99 & 35.3 & 0.387 & 22.9 & 4.06 & 22.3 & 69.38 & 6.05 & 40.34 & 13.49:1 \\
\hline $\begin{array}{l}\text { Farm-yard } \\
\text { manure + N }\end{array}$ & 2.90 & 33.5 & 0.379 & 20.3 & 3.92 & 18.1 & 69.03 & 5.51 & 40.13 & 11.89:1 \\
\hline Oxamyl & 3.70 & 67.4 & 0.460 & 46.0 & 4.68 & 40.9 & $\mathbf{7 2 . 7 0}$ & 11.12 & 42.27 & 11.42:1 \\
\hline $\mathrm{N}$ alone & 2.21 & _ & 0.315 & _ & $\mathbf{3 . 3 2}$ & _ & 65.42 & _ & $\mathbf{3 8 . 0 3}$ & 17.21:1 \\
\hline $\begin{array}{l}\text { Free of } \mathrm{N} \text { and } \\
\text { any } \\
\text { treatments }\end{array}$ & 2.30 & 4.1 & 0.356 & 13.0 & 3.4 & 2.4 & 66.30 & 1.34 & 39.0 & 16.95:1 \\
\hline
\end{tabular}

$\mathrm{N}=1000$ Meloidogyne incognita eggs.

Table (6) Average percentage of nitrogen(N), phosphorus(P), potassium(K), organic matter(O.M), and carbon in leaves of tomato plant CV. Caster Rock under the stress of Meloidogyne incognita infection treated with four animal manures and town refuse as post-planting applications comparing with oxamyl in greenhouse conditions.

\begin{tabular}{|c|c|c|c|c|c|c|c|c|c|c|}
\hline \multirow[b]{2}{*}{ Treatments } & \multicolumn{10}{|c|}{ * Chemical Component in Leaves } \\
\hline & $\mathbf{N} \%$ & Inc.\% & $\mathbf{P \%}$ & Inc.\% & K\% & Inc.\% & O.M\% & Inc.\% & O.C\% & $\mathbf{C} / \mathbf{N}$ \\
\hline $\begin{array}{l}\text { Chicken } \\
\text { manure }+\mathrm{N}\end{array}$ & 3.42 & 54.8 & 0.432 & 37.1 & 4.43 & 33.4 & 71.37 & 9.09 & 41.49 & 12.13 \\
\hline $\begin{array}{l}\text { Town } \\
\text { Refuse }+\mathbf{N}\end{array}$ & 5.58 & 16.7 & 0.350 & 11.11 & 3.68 & 10.8 & 67.40 & 3.02 & 39.19 & 15.19 \\
\hline Pigeon $+\mathrm{N}$ & 2.51 & 13.6 & 0.351 & 11.1 & 3.51 & 5.7 & 66.75 & 2.03 & 36.72 & 14.0 \\
\hline Horse + N & 2.82 & 27.6 & 0.373 & 18.4 & 3.92 & 18.1 & 68.61 & 4.87 & 39.89 & 14.15 \\
\hline $\begin{array}{l}\text { Farm-yard } \\
+\mathrm{N}\end{array}$ & 2.74 & 23.9 & 0.365 & 15.9 & 3.84 & 15.7 & 68.25 & 4.32 & 39.68 & 14.48 \\
\hline Oxamyl & 3.70 & 67.4 & 0.460 & 46.0 & 4.68 & 40.9 & 72.70 & 11.12 & 42.27 & 11.42 \\
\hline $\mathrm{N}$ alone & 2.21 & - & 0.315 & - & 3.32 & - & 65.42 & - & 38.03 & 17.21 \\
\hline $\begin{array}{l}\text { Free of } N \\
\text { and any } \\
\text { treatments }\end{array}$ & 2.30 & 4.1 & 0.356 & 13.0 & 3.4 & 2.4 & 66.30 & 1.34 & 39.0 & \\
\hline
\end{tabular}

$\mathrm{N}=1000$ Meloidogyne incognita eggs.

Data in Table (7) showed the nutrient constituents analysis of the tested organic soil amendments i.e. town refuse; chicken, horse, and farm-yard manure which varied remarkably in amounts of ammonium (in form of nitrogen), phosphorus, potassium, organic matter, organic carbon/nitrogen ratio. 
Effect of Five Organic Soil Amendments on Meloidogyne Incognita Infecting Tomato Plants under Greenhouse Conditions

Table (7): Approximate percentage of ammonium (nitrogen from), Potassium(K), Phosphorus(P), organic carbon(O.C) and Carbon / nitrogen (C/N ratio) of four animal manures and town refuse.

\begin{tabular}{|l|l|l|l|l|l|l|}
\hline \multicolumn{7}{|c|}{ Nutrient Constituent } \\
\hline $\begin{array}{c}\text { Materials of } \\
\text { organic } \\
\text { amendments }\end{array}$ & $\mathbf{N} \%$ & $\mathbf{P} \%$ & $\mathbf{K} \%$ & $\mathbf{O . M} \%$ & $\mathbf{O . C} \%$ & C/N \\
\hline $\begin{array}{l}\text { Chicken } \\
\text { manure }\end{array}$ & 2.71 & 0.559 & 1.78 & 66.7 & 38.8 & $14.3: 1$ \\
\hline Horse manure & 2.05 & 0.438 & 1.40 & 69.8 & 40.6 & $19.8: 1$ \\
\hline Pigeon manure & 3.02 & 0.592 & 1.97 & 65.4 & 38.1 & $12.6: 1$ \\
\hline $\begin{array}{l}\text { Farm-yard } \\
\text { manure }\end{array}$ & 1.83 & 0.389 & 1.32 & 64.2 & 37.3 & $20.4: 1$ \\
\hline Town refuse & 2.50 & 0.451 & 1.60 & 63.0 & 32.0 & $12.8: 1$ \\
\hline
\end{tabular}

Apparently, using animal manures and town refuse added as pre-planting or post planting treatments succeeded to improve tomato plant growth criteria and diminish nematode parameters as well as achieved the high percentage increase values of $\mathrm{N}, \mathrm{P}$, $\mathrm{K}, \mathrm{C}, \mathrm{O} . \mathrm{M}$ and total phenol comparing to nematode alone. Plant receiving pigeon manure as pre-planting or chicken manure as post-planting application at the level of $5 \mathrm{~g} /$ plant surpassed other tested animal manures and town refuse in the increment values of plant growth parameters and reduce nematode criteria as well. These findings are in agreement with those of $\mathrm{Gad}$ (2008) in respect to effect of organic manure on development of $M$. javanica infecting peanut plant. Organic amendments enhance soil fertility, improve biological and physical properties of soil, help in controlling root-knot nematodes and increase plant growth, since the majority of nitrogen in pigeon manure is in the form of uric acid and can be rapidly converted to ammonium nitrogen if temperature, $\mathrm{pH}$ and moisture are suitable for microbial activity (Sims and Wolf, 1994). The ammonium produced has been shown to kill parasitic nematodes (Eno et al., 1955).

Moreover, plants with fewer root galls would translocate more nutrients to vegetative organs than heavily galled roots (Oteifa and El- Gindi, 1962). The pigeon or chicken manures showed also very narrow $\mathrm{C} / \mathrm{N}$ ratio (12.6:1) or (14.3:1) in this work, a situation that can be supported by the findings of Miller and Donahue (1990) who reported that organic residues with C: $N$ ratio of $20: 1$ or narrow have sufficient nitrogen to supply the decomposing microorganisms and also to release for plant use. Improving of plant growth of tomato may be attributed to nematode elimentation and to the improvement of soil nutrients status (Akhtar and Mohamoud, 1996; Firoza and Maqbool, 1996). These result indicated that the tested organic matters showed positive effect on $M$. incognita development on tomato plant. These findings are in accordance with those reported by Akhtar and Mahmoud (1997) in respect to ammonia. Obviously, the present investigation showed that the nematicidial activity of the tested soil organic amendments against $M$. incognita on tomato can be varied from component to another. These differences may be due to the variation in the chemical nature composition concentration of both toxin materials present in these tested compounds and methods of adding followed. The safely of such materials and their low cost is on of their advantages. However, additional research work is needed using the integrated of more than one materials of such organic matters both in microplot and field experiments before recommendations can be made for integrated pest management (IPM).

\section{References}

1) A.O.A.C. (1980). Association of official Agriculture Chemist, official methods of Analysis. $13^{\text {th }}$ ed. Washington, D.C.

2) Akhtar, M. and I. Mahmood (1997). Impact of organic and inorganic management and plant-based products on plantparasitic and microbivorous nematode communities. Nematologia-Mediterranea 25(1): 21-23.

3) Akhtar, M. and I.Mahmoud (1996). Effect of plant based product "Nimin" and some plant oils on nematodes. Nematologia Mediterrania, 24:3-5.

4) Crow, W. T. and R. A. Dunn (2013). Soil organic matter, green manures and cover crops for nematode management. This document is ENY-059 (VH037), one of a series of the Entomology and Nematology Department, website at http://edis.ifas.ufl.edu.

5) EL-Sherif, A.G.; A.E.M. Khalil; A.R. Refaei and A.H. Nour EL-Deen (2006). Occurrence of white-tip nematode, Aphelenchoides besseyi in certain rice cultivation at South Dakahlia Governorate, Egypt and its management under field conditions. J. Agric. Sci. Mansoura Univ., 31(5):3215-3225.

6) El-Sherif, A.G.; Fatma A. Mostafa and A.A. Khalil (2001). Impact of Vinca rosea powder and oxamyl on controlling Rotylenchulus reniformis (Abstr.), IV. International Nematol. Symposium, Moscow, Russia 99 PP.

7) El-Sherif, A.G.; Fatma A. Mostafa and A.M. Zahir (2004). Impact of certain plant oil products and oxamyl on Meloidogyne incognita infecting sunflower plant. J. Agric. Sci. Mansoura Univ., 29 (2):935-942

8) Eno, C.F.; W.G. Blue and J.M. Good (1995). Effects of anhydrous ammonia on nematodes, fungi and bacteria in some florida soils. Soil Sci., 19: 55-58. http://dx.doi.org/10.2136/sssaj1955.03615995001900010013 
Effect of Five Organic Soil Amendments on Meloidogyne Incognita Infecting Tomato Plants under Greenhouse Conditions

9) Firoza, K. and M. M. Maqbool, (1996). Nematicidal properties of leaves some plant species against Helicotylenchus dihystera (Cobb, 1913) Sher, 1963 on tomato. Pakistan J. Nematol., 14:107-110.

10) Gad, S. B. (2008) Studies on nematodes associated with peanut crop. Msc. Thesis, Agric Zool. Dept. Agric Ac. Mansoura Univ. Egypt. 124 pp.

11) Hussey, R. S. and K. R. Baker (1973). A comparison of methods of collecting inocula of Meloidogyne spp. Including a new technique. Pl. Dis. Repte., 57: 1025-1028.

12) Ibrahim, I.K.A., and M.A. El-Saedy (1976). Plant parasitic nematodes associated with peanuts in Egypt. Egypt. J. Phytopath. $8: 31-35$.

13) Kaur, C. and H.C. Kapoor (2001). Antioxidants in fruits and vegetables \pm the millennium's health. International Journal of Food Science and Technology, 36, 703 \pm 725 . http://dx.doi.org/10.1111/j.1365-2621.2001.00513.x

14) McSorley R (2011). Overview of organic amendments for management of plant-parasitic nematodes, with case studies from Florida. J Nematol. 43(2):69-81.
15) Miller, R.W. and R. L. Donahue (1990).Organic matter and container media soils; An introduction to soils and Plant Growth. $6^{\text {th }}$ (Ed.). Prentice Hall, Inc., Englewood Cliffs, N.J. U.S.A.,181-225 pp.

16) Oteifa, B.A. and D.M. El-Gindi, (1962). Influence of parasitic duration of Meloidogyne javanica on host nutrient uptake.Nematologica, $8: 200-216$ http://dx.doi.org/10.1163/187529262x00459

17) Siddiqui, M.A. and M.M. Alam (1988). Control of plant parasitic nematodes by soil amendment with marigold plant wastes. Pakistan J. Nematol., 6(2): 55-63. http://dx.doi.org/10.1016/0269-7483(87)90128-5

18) Sims, J.T. and D.S. Wolf (1994). Poultry waste management: Agricultural and environmental issues. Adv. Agron., 52:1-83. http://dx.doi.org/10.1016/s0065-2113(08)60621-5

19) Taylor, A. L., and J. N. Sasser (1978). Biology, identification and control of root-knot nematodes (Meloidogyne species). Raleigh, NC: North Carolina State University Graphics.

20) Taylor, A. L., V. H. Dropkin, and G. C. Martin, (1955). Perineal patterns of root-knot nematodes. Phytopathology 45:26-34. 